\title{
CULTIVATING A FRIENDLY ATTITUDE: THE MASTER'S PROGRAM OF “ONE BELT ONE ROAD”, A THINK-TANK FOR INTERNATIONAL STUDENTS AT HARBIN INSTITUTE OF TECHNOLOGY
}

\author{
WEI DAI ${ }^{1}$, WIM RAVESTEIJN $^{2}$ \& JIANING MI ${ }^{1}$ \\ ${ }^{1}$ School of Management, Harbin Institute of Technology, China \\ ${ }^{2}$ Technology, Policy and Management, Delft University of Technology, The Netherlands
}

ABSTRACT

This paper describes a program for attaining a Master's degree at Harbin Institute of Technology in China, named "Belt and Road Think-Tank for Talent Strategy". This program is especially designed for cultivating the talents who will link the countries along "Belt and Road" with China under the new Silk Road cooperation framework. The program has designed an elaborate scheme of lectures to equip its candidates with scientific techniques in analyzing social problems and offers many opportunities to encourage students to participate in international debates. After two years of training, candidates in will be shaped into top-notch talents with a deep understanding of China. The port of Piraeus in Greece is introduced in this paper as an exemplary research thesis made by program candidates within the framework of this program. By analyzing the stakeholders involved, assessing the impacts brought by the project and resolving the value conflicts among diverse parties, responsible innovation is applied in mitigating the confrontation between a Chinese company (COSCO) and local Greek communities.

Keywords: annual conference, Belt and Road Initiative, China, Master's program, Piraeus, Silk Road Initiative.

\section{INTRODUCTION}

Launched by China in October 2013, the 21st Century Maritime Silk Road Initiative, the present One Belt One Road (OBOR) program or the Belt and Road Initiative (BRI), is an ambitious initiative which aims to promote the common development and prosperity of Europe, Africa and Asia [1]. Under the principles of "Open for Cooperation", "Harmonious and Inclusive," "Market Operation" and "Seeking Mutual Benefits" on land, the initiative focuses on building a land bridge which connects Eastern Asia and Western Europe. At sea, it engages in jointly building smooth, secure and efficient transportation routes connecting major sea ports. The program intends to integrate all countries along the "Belt and Road" into an economic corridor, greatly strengthening the connections between the Western Pacific, the Indian Ocean and the Mediterranean Sea [2].

\section{TALENT SHORTAGE}

With the proliferation of the OBOR initiative globally, tremendous cooperative potential is being tapped: China opening its huge consumption market to foreign companies, while other countries also open their markets to Chinese organizations, expanding their global businesses; however, excellent human talents are required to guarantee this development: currently, qualified people are in great shortage, especially those who are able to successfully connect China with these countries.

\section{THE BELT AND ROAD THINK-TANK FOR TALENT STRATEGY}

Considering this talent shortage and for the purpose of fulfilling an international university's responsibilities in terms of cultivating talents that are adapted to our changing world, Harbin 
Institute of Technology (HIT) launched its talent program "Belt and Road Think-Tank for Talent Strategy" (BRTT).

\subsection{Objectives}

This is a program aimed at cultivating multidisciplinary, intercultural and versatile international think-tank talents. It combines the education and research of the international students, with the economic backgrounds and customs of their countries. Therefore, the program has had clear objectives since its establishment:

- Cultivate top-notch think-tank talents for the surrounding OBOR countries,

- Establish an intelligent bridge and friendships between China and OBOR countries,

- Build an intelligent network supporting the OBOR initiative, and

- Build strategic relationships among all countries with access.

\subsection{The program}

To achieve these goals, HIT designed an elaborate scheme of lectures for all candidates, despite their background diversity. In fact, HIT intends to equip students not only with many analytical tools, including Cost Benefit Analysis, statistical analysis and dealing with Big Data; but also with knowledge of the Chinese language and economics. All these courses will on the one hand, help foreign students get a deeper understanding of the OBOR initiative and a better image of China; while on the other hand, these techniques will enable them to integrate their own knowledge into OBOR projects in their home countries. The master's program takes two years: one year of courses and one, writing a master's thesis (Table 1).

Table 1: Course description.

\begin{tabular}{|c|c|c|c|c|c|}
\hline $\begin{array}{l}\text { Course } \\
\text { type }\end{array}$ & Course name & Hours & Credits & Semester & Notes \\
\hline \multirow{9}{*}{$\begin{array}{l}\text { Degree } \\
\text { Courses }\end{array}$} & The Course of Primary Chinese Oral I & 64 & 2 & Autumn & Required \\
\hline & The Course of Primary Chinese Oral II & 64 & 2 & Spring & Required \\
\hline & $\begin{array}{l}\text { Chinese Culture; } \\
\text { Cross-culture Communication }\end{array}$ & 32 & 2 & Spring & Required \\
\hline & Think-Tank and Governance Theory & 32 & 2 & Autumn & Required \\
\hline & Economic Principles & 32 & 2 & Autumn & Required \\
\hline & Regional Development Strategy \& Planning & 32 & 2 & Autumn & Required \\
\hline & Public Policy Analysis & 32 & 2 & Spring & Required \\
\hline & Applied Statistical Analysis & 32 & 2 & Autumn & Required \\
\hline & Methods of Social Research & 16 & 1 & Spring & \\
\hline \multirow{11}{*}{$\begin{array}{l}\text { Optional } \\
\text { Courses }\end{array}$} & Big Data and E-government & 32 & 2 & Autumn & \\
\hline & Theory and Method of Impact Assessment & 32 & 2 & Spring & \\
\hline & Cost-benefit Analysis of Public Projects (CBA) & 32 & 2 & Autumn & \\
\hline & Economic Geography and Regional Policy & 32 & 2 & Spring & \\
\hline & Information Technology and E-commerce & 16 & 1 & Spring & \\
\hline & Interpretation of "R\&B" Policy & 16 & 1 & Spring & \\
\hline & Policy Network; Intergovernmntl. Cooperation & 16 & 1 & Spring & \\
\hline & Intercultural Communication & 16 & 1 & Spring & \\
\hline & Study of American Think-Tank & 16 & 1 & Spring & \\
\hline & Energy Economics and Policy & 16 & 1 & Spring & \\
\hline & Mobile and Social Commerce & 16 & 1 & Spring & \\
\hline Required & Academic Communication & & 2 & & \\
\hline Required & Thesis Proposal & & 1 & & \\
\hline
\end{tabular}




\subsection{Achievements}

After two years of training, candidates in this program will have been shaped into top-notch talent with a specially friendly attitude towards China.

\subsubsection{An example}

Offering their individual insights to the authorities, in terms of contributing to the OBOR initiative, some candidates were highly valued by their home countries. This applied, for example, to a program candidate from Tanzania, who was invited to attend the African Youth Leadership Forum in 2018. During the forum, she had a presentation in terms of what she had experienced and learned from the program, combined with her personal insights. The presentation received recognition from the attendees, especially young people from Africa. As a result, she was received by the president and prime minister of Tanzania. Furthermore, she was nominated as one of the 100 Tanzanian Sheroes 2018 (Fig. 1).
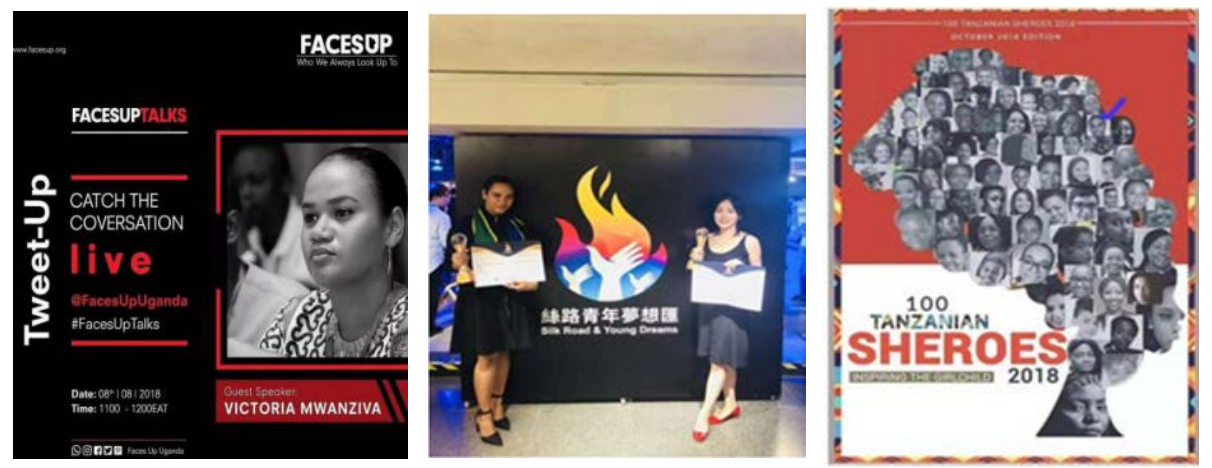

Figure 1: Student photos.

\subsubsection{International Symposium}

The International Symposium on the BRI for the Think-Tank Network is a symposium, which aims to bring leading academic scientists and research scholars from China and Europe together, to exchange and share their experiences and research results about all aspects of the BRI. The symposium was initiated by HIT, in the framework of the BRI master program with clear objectives, reflecting the master's program goals:

- Cultivate top-notch think-tank talents for European countries of the BRI

- Establish an intelligent bridge and friendly relationships between China and all the Central and Eastern Europe BRI countries

- Build an intelligent BRI network connecting all these countries

- Build strategic relationships between the Central and Eastern European BRI countries, so that all these countries can develop together.

It was first held between 25-26 November 2017 (Fig. 2). Researchers from Russia, Ukraine, Mongolia, Hungary and Lithuania were invited to visit HIT, to sit down and freely exchange their OBOR insights. In 2018, the symposium took place from 15-16 October (Fig. 2). The symposium was a great success. Researchers presented their latest achievements with regard to topics, such as: 
- The BRI and China's actions

- The "Central and Eastern Europe Silk Road" as part of the BRI

- Cultivation of top-notch think-tank talent from Central and Eastern Europe

- Exchange of experiences regarding the Belt and Road think-tank master's program
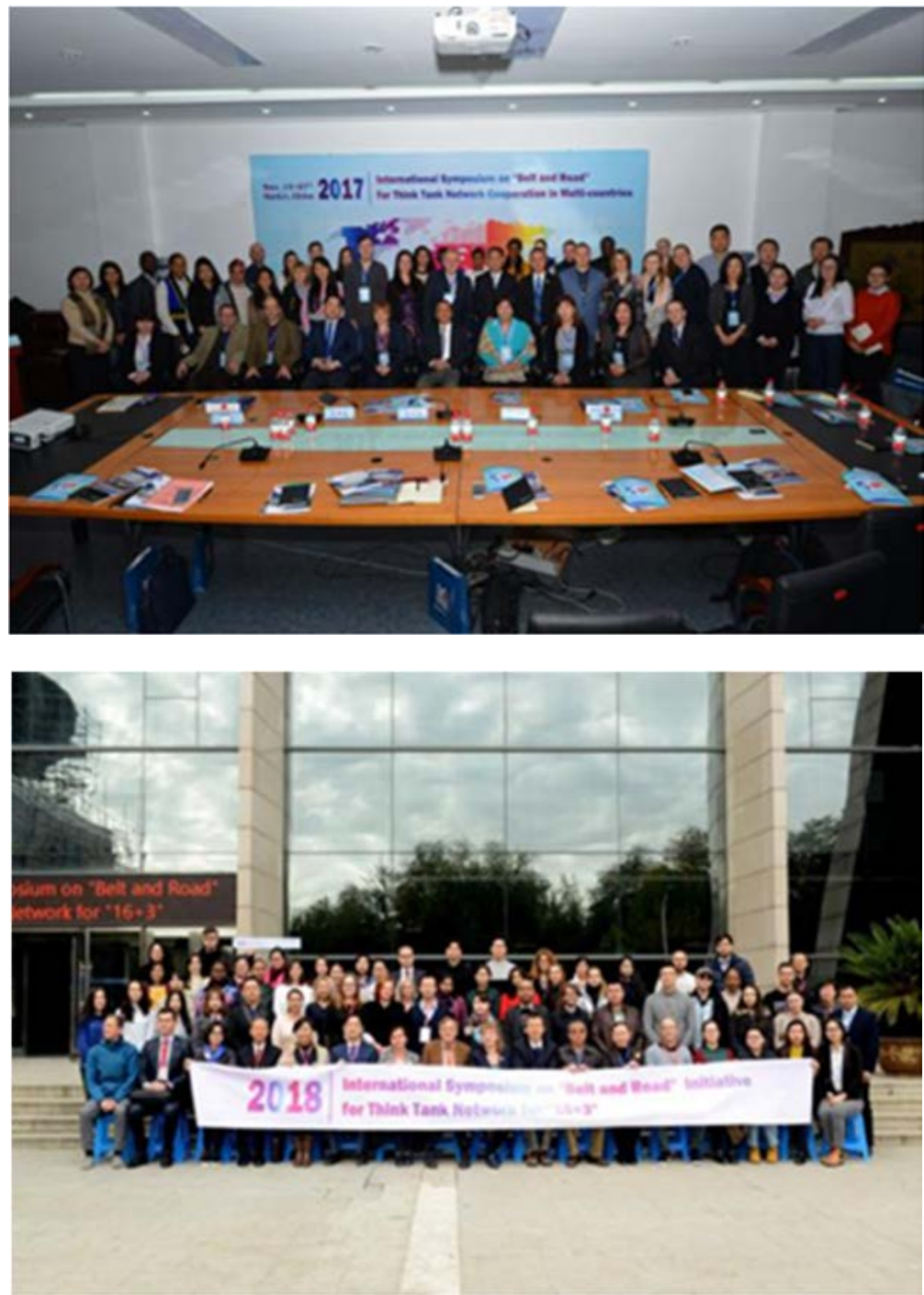

Figure 2: 2017 and 2018 International Symposiums.

Through this symposium, the BRI Think-Tank for Talent Strategy program can not only accomplish its tasks as originally formulated, "to cultivate qualified talents to meet the demands of OBOR talent shortage," it also strengthens the connections between the peoples of the involved countries. 


\section{THE PIRAEUS PORT PROJECT}

After a two-year time period getting professional training, students from the program are capable of applying the theories learned in solving practical problems. A good example is the successful application of sustainable development, stakeholder analysis, impact assessment and addressing value conflicts; in the case of a Chinese company that was expanding its overseas operations to the port of Piraeus, Greece.

\subsection{Background information}

Piraeus is a crucial knot in China's international transportation and logistics network [4]. Geographically, it stands in the center of the Mediterranean area, with shipping routes to manifold destinations. As the port of Piraeus will be linked by railways to Central Europe under the OBOR framework, there will be a shorter transportation pathway for ChineseEuropean trade. In 2008, the Chinese company Cosco obtained a concession from the Piraeus Port Authority (PPA) to operate the port's container terminal for a period of 35 years [11].

\subsection{Win-win deal between China and Greece}

Since the Chinese company Cosco took over the two terminals of Piraeus and started to further develop them, a rapid growth in container throughput and profit could be observed. In 2008, Piraeus was a low-level efficiency port in Mediterranean area. From 2009 until 2014, the container throughput at Piraeus increased five-fold, from 0.7 million to 3.6 million TEU [3]. Moreover, Piraeus was ranked at the top, in terms of the growth rate of the container throughput from 2011 to 2014, in the Containerization International magazine.

In 2014, Piraeus reached 3 million TEU for the first time, and was able to contribute 34 million euros in profits to Cosco [3]. Cosco's investments in Piraeus not only brought the company considerable profits, but also seemed to benefit Greek society. The project looks like a win-win deal for both. For Cosco, the Piraeus port already generated a profit of 34 million euro by 2014, and it is expected to sustainably contribute to the company's development in the future. In addition, the project is a significant realization of Cosco's "Step Out" strategy, which not only covers the expansion of its business to Europe, but also the accumulation of cherished experiences, in terms of operating a port project in an intercultural environment [4].

The Piraeus project also had positive impacts on Greece. On the one hand, Cosco's investments brought a huge amount of funds, updated technologies, as well as advanced administrative concepts in Greece. Greece urgently requires all of these at the moment, as it is trapped in a debt crisis. On the other hand, the project helped to create job opportunities. By the end of May 2014, the unemployment rate of Greece was 27.8\%; however, the port expansion project alone directly brought 1100 jobs, which raised the employment rate by $0.023 \%$, absorbing $0.6 \%$ of the local workforce [5].

\subsection{Protests from the Greek people}

Theoretically, Cosco's involvement in Piraeus should have been a successful example for foreign companies, especially Chinese enterprises willing to expand their business overseas; however, it turned out that the Greek citizens regarded this cooperation as a threat, instead. According to Reuters: "Dockworkers walked out on Friday and marched in central Athens to protest against the deal, which they fear will put their jobs at risk" [6]. People were also concerned about the pollution caused by the project. 


\subsection{Research question}

Cosco started a port development project in Piraeus, but its failure in controlling all the economic, environmental and social risks could lead to the company eventually failing at its business activities in Piraeus. Therefore, students who have been trained by the HIT BRTT program would like to apply theories to help Cosco analyze its problems and eradicate its dilemma: How can Cosco address its economic, environmental and social conflicts with the other stakeholders in Piraeus? Three techniques will be applied to address this question.

\subsection{Methodology}

1. Stakeholder analysis: This type of analysis is used for the purpose of better understanding the intertwined relationships between the various stakeholders. Stakeholders involved in the project have different interests, objectives and resources. Motivated by their interests and objectives, they will use their resources to influence the decision-making of the port. They also have interdependencies with regard to achieving their goals. By doing a stakeholder analysis, the results of this research will enable a deeper understanding of the people involved, which will potentially be helpful in terms of solving the conflicts in Piraeus.

2. Impact assessment: The impacts brought about by the project must be determined, as well as the extent to which these effects affect the stakeholders. It is generally assumed that the protests result from the consequences of the project, damaging the interests of stakeholders or preventing them from achieving their objectives. Also, that because they have a lack of ways to express their dissatisfaction, they have chosen to demonstrate. The solution here might be stakeholder involvement, but first the impacts and their distribution among the stakeholders must be mapped out.

3. Value analysis: This analysis aims to list the values of each stakeholder, as well as the value conflicts between them. From the points of view of sustainable development and responsible innovation, conflicts of interest and goals between actors are only contradictions on the surface, while the essential conflicts regard values. To permanently mitigate their disagreement, reconciling the value conflicts is the right way, which can be addressed through stakeholder engagement.

\subsection{Analysis}

\subsubsection{Stakeholder analysis}

Questions: Who is involved in this project? Who is influenced by it? The problem owner, in this case, is Cosco.

In addition to this key stakeholder, the PPA, Piraeus local businesses, local labor and the surrounding inhabitants are the main stakeholders. All of these actors have collectively shaped the current situation in Piraeus. Cosco, PPA, other firms, laborers and the inhabitants have multiple interests and goals, and also different resources in terms of abilities to exert influence on the decision-making in each distinct phase. Cosco has a high dependency on PPA and local companies, but a low dependency on the other stakeholders (Table 2).

\subsubsection{Impact assessment}

What impacts do the actors have through this project? There are multiple economic, environmental and social effects for the actors: sometimes for all actors, sometimes for a varying number of groups (Table 3 ). 
Table 2: Stakeholder analysis.

\begin{tabular}{|c|c|c|c|}
\hline Actors & Interests & Objectives/goals & Resources \\
\hline $\begin{array}{l}8 \\
\dot{y} \\
0\end{array}$ & $\begin{array}{l}\text { Economically: } \\
\text { (1) Throughput of the port; } \\
\text { (2) Profits of the port; } \\
\text { (3) Costs of the construction } \\
\text { and operation; } \\
\text { (4) Number of tourists and } \\
\text { businesses; } \\
\text { (5) Policy bonus of OBOR } \\
\text { initiative; } \\
\text { Socially: } \\
\text { (6) Public opposition; } \\
\text { Environmentally: } \\
\text { (7) Pollution. }\end{array}$ & $\begin{array}{l}\text { Economically: } \\
\text { (1) Increasing throughput of the port; } \\
\text { (2) Higher profits of the port; } \\
\text { (3) Lower costs of construction and } \\
\text { operation; } \\
\text { (4) Increasing the number of tourists } \\
\text { and businesses; } \\
\text { (5) Maximizing policy bonus under } \\
\text { OBOR initiative; } \\
\text { Socially: } \\
\text { (6) Less public opposition; } \\
\text { Environmentally: } \\
\text { (7) Reach for the lowest pollution. }\end{array}$ & $\begin{array}{l}\text { Implementational } \\
\text { power }\end{array}$ \\
\hline$\underset{a}{\overleftrightarrow{a}}$ & $\begin{array}{l}\text { Economically: } \\
\text { (1) Fiscal income; } \\
\text { (2) Port economy; } \\
\text { (3) Public expenditure; } \\
\text { Socially: } \\
\text { (4) Public support (public } \\
\text { opposition); } \\
\text { (5) Employment; } \\
\text { Environmentally: } \\
\text { (6) Environment quality } \\
\text { (pollution); } \\
\text { (7) Energy consumption. }\end{array}$ & $\begin{array}{l}\text { Economically: } \\
\text { (1) More fiscal income; } \\
\text { (2) Prosperity of the port economy; } \\
\text { (3) Less public expenditure; } \\
\text { Socially: } \\
\text { (4) Higher public support and less } \\
\text { public opposition; } \\
\text { (5) Higher employment rate; } \\
\text { Environmentally: } \\
\text { (6) Better environment quality (less } \\
\text { pollution); } \\
\text { (7) Sustainable development. }\end{array}$ & Political power \\
\hline 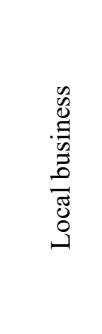 & $\begin{array}{l}\text { Economically: } \\
\text { (1) Cost of business; } \\
\text { (2) Number of businesses; } \\
\text { Socially: } \\
\text { (3) Public security; } \\
\text { Environmentally: } \\
\text { (4) Pollution. }\end{array}$ & $\begin{array}{l}\text { Economically: } \\
\text { (1) Lower cost (achieved by lower } \\
\text { transportation fees with the port } \\
\text { development); } \\
\text { (2) A bigger and booming, consuming } \\
\text { market; } \\
\text { Socially: } \\
\text { (3) Better public security; } \\
\text { Environmentally: } \\
\text { (4) Reach the lowest pollution. }\end{array}$ & $\begin{array}{l}\text { Consultative, } \\
\text { commentative and } \\
\text { demonstrative } \\
\text { power }\end{array}$ \\
\hline 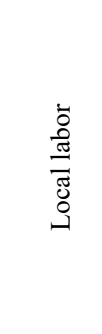 & $\begin{array}{l}\text { Economically: } \\
\text { (1) Income; } \\
\text { (2) Living expense; Socially: } \\
\text { (3) Social welfare; } \\
\text { (4) Public security; } \\
\text { Environmentally: } \\
\text { (5) Environment quality } \\
\text { (pollution); } \\
\text { (6) Natural scenery. }\end{array}$ & $\begin{array}{l}\text { Economically: } \\
\text { (1) Higher income; } \\
\text { (2) Lower living expenses; } \\
\text { Socially: } \\
\text { (3) Better social welfare; } \\
\text { (4) Better public security; } \\
\text { Environmentally: } \\
\text { (5) Better environmental quality (less } \\
\text { pollution); } \\
\text { (6) Better natural scenery. }\end{array}$ & $\begin{array}{l}\text { Consultative, } \\
\text { commentative, } \\
\text { demonstrative } \\
\text { power and strike }\end{array}$ \\
\hline 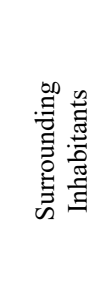 & $\begin{array}{l}\text { Economically: } \\
\text { (1) Living expense; } \\
\text { Socially: } \\
\text { (2) Social welfare; } \\
\text { (3) Public security; } \\
\text { Environmentally: } \\
\text { (4) Environmental quality } \\
\text { (pollution); } \\
\text { (5) Natural scenery. }\end{array}$ & $\begin{array}{l}\text { Economically: } \\
\text { (1) Lower living expenses; } \\
\text { Socially: } \\
\text { (2) Better social welfare; } \\
\text { (3) Better public security; } \\
\text { Environmentally: } \\
\text { (4) Better environmental quality (less } \\
\text { pollution); } \\
\text { (5) Better natural scenery. }\end{array}$ & $\begin{array}{l}\text { Consultative, } \\
\text { commentative and } \\
\text { demonstrative } \\
\text { power }\end{array}$ \\
\hline
\end{tabular}


Table 3: Impacts and actors.

\begin{tabular}{|c|c|c|}
\hline \multicolumn{2}{|l|}{ Impacts } & Actors being influenced \\
\hline \multirow{5}{*}{ Economic } & Property losses & $\begin{array}{l}\text { Local companies, local laborers and } \\
\text { surrounding inhabitants }\end{array}$ \\
\hline & $\begin{array}{l}\text { Restrictions in using natural } \\
\text { resources }\end{array}$ & $\begin{array}{l}\text { Local companies, local laborers and } \\
\text { surrounding inhabitants }\end{array}$ \\
\hline & $\begin{array}{l}\text { Increasing the revenue of the } \\
\text { port }\end{array}$ & Cosco, PPA, Local companies \\
\hline & $\begin{array}{l}\text { Lower the cost of cargo } \\
\text { transportation and travel }\end{array}$ & $\begin{array}{l}\text { Cosco, PPA, local companies, } \\
\text { laborers and surrounding } \\
\text { inhabitants }\end{array}$ \\
\hline & $\begin{array}{l}\text { Prosperity of the port } \\
\text { economy }\end{array}$ & All actors \\
\hline \multirow{5}{*}{ Environmental } & Construction waste & \multirow{5}{*}{ All actors } \\
\hline & Water pollution & \\
\hline & $\begin{array}{l}\text { Natural ecosystem destroyed, } \\
\text { landscape changed }\end{array}$ & \\
\hline & Air pollution & \\
\hline & Noise pollution & \\
\hline \multirow{4}{*}{ Social } & $\begin{array}{l}\text { Polarization between the rich } \\
\text { and the poor }\end{array}$ & All actors \\
\hline & $\begin{array}{l}\text { Social problems related to } \\
\text { pollution }\end{array}$ & PPA, Cosco and local companies \\
\hline & $\begin{array}{l}\text { Destruction of the social order } \\
\text { and public security }\end{array}$ & $\begin{array}{l}\text { Local companies, laborers and } \\
\text { surrounding inhabitants }\end{array}$ \\
\hline & Higher employment rate & All actors \\
\hline
\end{tabular}

PPA: Piraeus Port Authority.

\subsubsection{Value analysis}

Why are the actors against the project? Why in favor? That depends on their interests and objectives, and ultimately, their values. Table 4 shows the economic, environmental and social core values of the various actors, specified per actor.

On the basis of the impacts in Table 3 and the values in Table 4, several value conflicts between Cosco and other actors can be identified, including the following:

A. Cosco and PPA

Cosco and PPA both suffer from the following impacts: 
Table 4: Actors and values.

\begin{tabular}{|c|c|}
\hline Actors & Value \\
\hline Cosco & $\begin{array}{l}\text { Economically: Higher profits } \\
\text { Socially: A positive public image (serves for economic value: higher } \\
\text { profit) } \\
\text { Environmentally: Legal operation (serves for economic value: higher } \\
\text { profit) }\end{array}$ \\
\hline PPA & $\begin{array}{l}\text { Economically: Higher fiscal income, economic development } \\
\text { Socially: Fulfill its responsibility as an authority: effective social } \\
\text { management } \\
\text { Environmentally: Fulfill its responsibility as an authority: effectively } \\
\text { protect the environment and sustainable development }\end{array}$ \\
\hline Local business & $\begin{array}{l}\text { Economically: Higher profits } \\
\text { Socially: A friendly business environment (serves for economic value: } \\
\text { higher profits) } \\
\text { Environmentally: Legal operation (serves for economic value: higher } \\
\text { profits) }\end{array}$ \\
\hline Local labor & $\begin{array}{l}\text { Economically: Higher income, fewer economic losses } \\
\text { Socially: Better livability } \\
\text { Environmentally: Better livability }\end{array}$ \\
\hline $\begin{array}{l}\text { Surrounding } \\
\text { inhabitants }\end{array}$ & $\begin{array}{l}\text { Economically: Fewer economic losses } \\
\text { Socially: Better livability } \\
\text { Environmentally: Better livability }\end{array}$ \\
\hline
\end{tabular}

PPA: Piraeus Port Authority.

- Environmental problems, such as construction waste, water pollution, natural ecosystem destruction and a changed landscape (negatively!), air pollution and noise pollution.

- Some social governance issues, including the polarization between the rich and the poor, social problems related to pollution, the destruction of the social order and public security.

Given their value background; however, these impacts have different meanings for the actors. As the administration of the port, PPA has environmental and social values (to fulfill its responsibility as an authority: effectively organize society and effectively protect the environment), which are in conflict with Cosco's economic value motivation (higher profits). Nevertheless, PPA and Cosco are not involved in intensive value conflicts.

B. Cosco and local companies

Cosco profits, while local companies suffer from the following impacts: 
- Property losses

- Restriction in using natural resources

- A higher employment rate.

Property losses, restriction in using natural resources and a higher employment rate (to be understood as an overheated labor market) can lead the local companies to spend more on their business, while seeing their profits decrease. Essentially, local companies' economic value of higher profit conflicts with Cosco's similar economic value, where local businesses seems to lose, while Cosco seems to win.

C. Cosco, local laborers and the surrounding inhabitants

The following impacts are relevant in considering conflicts between Cosco, local laborers and the surrounding inhabitants:

- Economic losses.

- Restrictions in using natural resources.

- Increasing of revenue of the port.

- Environmental problems, including construction waste, water pollution, the natural ecosystem being destroyed and the landscape changed, air and noise pollution.

- Polarization between the rich and the poor.

- Social problems related to environmental problems.

- Destruction of the social order and of public security.

Essentially, there are two value conflicts between local laborers, the surrounding inhabitants and Cosco:

- Local labors' economic values of having a higher income and less economic losses conflict with Cosco's economic value of making a higher profit. Due to the fact that Cosco has only focused on its profits, it had restricted the other actors' rights in using the natural resources; brought about dismissal waves and thus, severely harmed the workers' interests. The port has increased its revenues, but local people did not share in this development outcome. Cosco continues to benefit from the port, while workers are/did not. In terms of wealth distribution, the two actors are clearly in disagreement.

- The social and environmental value of better livability, shared by local laborers and the surrounding inhabitants, conflicts with Cosco's economic higher profit value. As Cosco focused on profit, the port has experienced economic success; however, this development has also caused many economic, environmental and social issues to occur. Local laborers and the inhabitants, which are essentially the same people, have suffered from economic losses, pollution and many other related social problems. To improve the current situation, Cosco has to invest more in social matters (such as compensation funds for the local people's economic losses, sharing a greater part of its profits with its workers), as well as in environmental and social governance; however, this would certainly be at the expense of its economic value of having higher profits.

\subsection{Conclusions}

PPA (the Piraeus Port Authority), the Piraeus local companies, the local laborers, and the surrounding inhabitants were identified as being the main stakeholders who were influenced 
by Cosco's project. These actors have diverging interests, goals and resources, while playing different roles in Piraeus decision-making processes.

In terms of impact, the Piraeus project brought about property losses to some local people. In addition, people's rights of using the natural resources have been restrained. At the same time, with the progress of the project, the port generated sustainable profits to Cosco, while PPA also benefited, through increased fiscal revenues.

The fees spent on cargo transportation and on travel are getting lower, and the port economy is growing. Environmentally, many problems have emerged. Waste pollution, water pollution, air pollution and noise pollution do severely reduce the livability of Piraeus. The natural ecosystem was destroyed, the landscape was affected and the people suffered terribly from the project. Socially, society became more divided, with the rich getting richer while the poor were getting poorer. Economic losses, pollution and cultural issues have increased people's uncertainties and the people have become more fearful and dissatisfied with the project, even though the project has created thousands of job opportunities and the employment rate has experienced a dramatic rise.

Cosco and other actors have various conflicts, in terms of interests, goals and values; while they also have and experience different impacts. PPA and Cosco have a slight disagreement as to environmental problems (including construction waste, water pollution, the destruction of the natural ecosystem, the landscape affected, air and noise pollution, and social governance). Local companies and Cosco have conflicts regarding the property losses, restrictions in using the natural resources and employment problems. Laborers and inhabitants are dissatisfied with Cosco's activities, which have led to economic losses, restrictions in using the natural resources, destruction of the natural environment and social problems.

Diverging stakeholder values are at the core of these conflicts. Cosco's main value is higher profit. Its social and environmental values are subordinate to this. Consequently, in the Piraeus project, Cosco has collided with PPA where it comes to its responsibilities as the port authority, with local companies also striving for a higher profit and with the laborers and inhabitants with regard to their economic, environmental and social values of expecting less property loss and livability.

\subsection{Recommendations}

How can Cosco address its economic, environmental and social conflicts with the other stakeholders in Piraeus?

\subsubsection{Governance mechanism}

A governance mechanism can be introduced, in order to resolve the type of value conflicts present in the case of Piraeus [7]. Such a governance mechanism has already been tested in the case of the port of Rotterdam, where a Quality Control Round Table was established, consisting of representatives of all involved parties [8], [9] (cf. [10]).

\subsubsection{Multi-Actor Negotiation Committee}

Cosco could establish a Multi-Actor Negotiation Committee (MANC). This committee would consist of all the stakeholders involved in this project, from its infancy to its future operation period. Cosco, PPA and representatives of local businesses, local labor and the surrounding inhabitants, even a representative from the international companies, are invited to join this committee, and to discuss and prepare each crucial decision to be taken in the project. 


\section{CONCLUSIONS}

Harbin Institute of Technology (HIT) started the Belt and Road Think-Tank for Talent Strategy master's degree program to cultivate top-notch talent for the countries involved in the One Belt One Road Initiative, to establish friendly relationships between China and these OBOR countries, in order to build supportive networks and strategic relationships.

The program attracts foreign students from African, East and Central European and other OBOR countries; while within its framework, an annual international conference is to be organized to which foreign experts are invited. An analysis of the events in the port of Piraeus in Greece, where the Chinese company Cosco started a port development project, has been presented as an example of the type of issues the program is meant to address and the types of analyses used to work on solutions. It turns out that a combination of stakeholder analysis, impact assessment and value analysis can clarify Cosco's problems and help to formulate a solution strategy in the form of a Multi-Actor Negotiation Committee.

\section{REFERENCES}

[1] Len, C., China's 21 st century maritime silk road initiative, energy security and SLOC access. Maritime Affairs (Journal of the National Maritime Foundation of India), 11(1), pp. 1-18, 2015.

[2] Van der Putten, F.P. \& Meijnders, M., China, Europe and the Maritime Silk Road, The Netherlands Institute of International Relations: Clingendael, 2015.

[3] Van der Putten, F.P., Chinese Investment in the Port of Piraeus, Greece: The Relevance for the EU and the Netherlands, The Netherlands Institute of International Relations: Clingendael, 2014.

[4] 胥苗苗, 中远海运收购比港启示. 中国船检, 4, pp. 58-61, 2016. (In Chinese.)

[5] Foundation for Economic and Industrial Research (IOBE), The economic impact of the privatisation of the Piraeus Port Authority; 2016.

http://iobe.gr/docs/research/RES_03_08032016_REP_GR.pdf. Accessed on: 15 Nov. 2018.

[6] Reuters, Workers protest as Greece sells Piraeus Port to China COSCO, 8 April 2016. www.reuters.com/article/us-eurozone-greece-privatisation-china-cidUSKCN0X50ZE. Accessed on: 15 Nov. 2018.

[7] Dix, J., Better Scope Management during the Initiative, Design and Construction Phase of Infrastructure Projects, Master's thesis, TU Delft, 2010.

[8] Dekker, S., Quality Control Round Table MV2, 2013. http://annualreport.portofrotterdam.com/en/stakeholders/sybilla-dekker/2219? paragraaf $1 / 42228$.

[9] Dix, J., Better Scope Management during the Initiative, Design and Construction Phase of Infrastructure Projects, Master's thesis, TU Delft, 2010.

[10] Lichtenberg, J.J.N., Maak innovatie hsl en Betuwelijn transparant. Cobouw, 2005. (In Dutch.)

[11] Piraeus Port Authority Web Site, www.olp.gr/en/. Accessed on: 19 Nov. 2018. 